\title{
Studies on Physicochemical Properties of Biofield Treated 2,4-Dichlorophenol
}

\author{
Mahendra Kumar Trivedi ${ }^{1}$, Alice Branton ${ }^{1}$, Dahryn Trivedi ${ }^{1}$, Gopal Nayak $^{1}, \operatorname{Ragini} \operatorname{Singh}^{2}$, \\ Snehasis Jana ${ }^{2, *}$ \\ ${ }^{1}$ Trivedi Global Inc., Henderson, NV, USA \\ ${ }^{2}$ Trivedi Science Research Laboratory Pvt. Ltd., Bhopal, Madhya Pradesh, India
}

Email address:

publication@trivedisrl.com (S. Jana)

\section{To cite this article:}

Mahendra Kumar Trivedi, Alice Branton, Dahryn Trivedi, Gopal Nayak, Ragini Singh, Snehasis Jana. Studies on Physicochemical Properties of Biofield Treated 2,4-Dichlorophenol. American Journal of Environmental Protection. Vol. 4, No. 6, 2015, pp. 292-299.

doi: 10.11648/j.ajep.20150406.15

\begin{abstract}
The chlorinated phenols are widely used in chemical industries for the manufacturing of herbicides, insecticides, etc. However, due to consistent use they create hazards to the environment. This study was designed to use an alternative method i.e. biofield energy treatment and analyse its impact on the physicochemical properties of 2,4-dichlorophenol (2,4DCP), which are the important factors related to its degradation. The 2,4-DCP sample was treated with Mr. Trivedi's biofield energy and analyzed as compared to the untreated 2,4-DCP sample (control) using various analytical techniques. The X-ray diffraction studies revealed up to $19.4 \%$ alteration in the lattice parameters along with approximately $1.8 \%$ alteration in the molecular weight, unit cell volume and density of the treated sample. The crystallite size of treated sample was increased and found as $215.24 \mathrm{~nm}$ as compared to $84.08 \mathrm{~nm}$ in the control sample. Besides, the thermal study results showed an alteration in the thermal stability profile of the treated sample as compared to the control. The differential scanning calorimetry studies revealed the decrease in the thermal decomposition temperature from $137.9^{\circ} \mathrm{C}$ (control) to $131.94^{\circ} \mathrm{C}$ in the treated sample along with $92.19 \%$ alteration in the quantity of heat absorbed during the process. Moreover, the thermogravimetric analysis showed that onset temperature of degradation was decreased, while the percent weight loss of the sample was increased from $59.12 \%$ to $71.74 \%$ in the treated sample as compared to the control. However, the Fourier transform infrared and UV-visible spectroscopic studies did not show any significant alteration in the spectra of the treated sample as compared to the control. Hence, the overall studies revealed the impact of biofield energy treatment on the physical and thermal properties of the 2,4DCP sample.
\end{abstract}

Keywords: 2,4-Dichlorophenol, Biofield Energy Treatment, Pollutants, Complementary and Alternative Medicine

\section{Introduction}

The chlorinated derivatives of phenols are an important class of pollutants that originate from the industrial chemicals [1]. They are non-biodegradable and hence remain in the environment for a longer duration. 2,4-dichlorophenol $(2,4$ DCP) is a widely used chlorinated phenol that comes under the category of industrial toxic compounds and listed by United State Environmental Protection Agency (US EPA) as primary pollutants $[2,3] .2,4-\mathrm{DCP}$ is used as a precursor in the synthesis of 2,4-dichlorophenoxy acetic acid (2,4-D), an herbicide. Other uses include as a wood preservative, insecticide, plant growth regulator, etc. [4, 5]. However, due to the consistent use, it poses hazards to the environment hence, these toxic and bio-resistant compounds need to be removed from the environment or transformed into some other form that are less harmful.

When a chemical enters the environment, it distributes itself in the different compartments viz. air, water, soil and living organisms. Moreover, the distribution, as well as degradation of the chemical from these compartments, were decided by the physicochemical properties of that chemical. These properties include molecular weight, solubility, volatilization, and polarity, etc. [6, 7]. The environmental fate of 2,4-DCP from the aquatic surface and the soil surface is expected through the volatilization process $[8,9]$. Its molecules reach in the atmosphere through the process of volatilization where they degraded by reacting with the 
photochemically produced free radicals [10]. However, this process is slow and not suitable for high concentration of pollutants. Recently, several processes are designed for making this process fast that include advanced oxidation processes [11], but they are not very much cost- effective. Therefore, it is of great significance to search an alternative strategy that can help in the fast degradation of these chemicals from the environment in a cost effective manner. Biofield energy treatment is recently known for its ability in altering the physicochemical properties of several metals and organic compounds [12, 13]. Biofield energy is scientifically related to the human energy field that is formed by the body in the surrounding space. This energy field is generated by the physical and thought processes of the human body and its interaction with the environment [14]. The living organisms are regularly exchanging this energy with the surroundings to maintain themselves [15]. The biofield energy and its interaction with the environment are used by the practitioners as the healing therapies. Its effectiveness was reported in the reduction of tension, anxiety and pain. Moreover, these therapies are considered as complementary and alternative medicines (CAM) by National Institute of Health (NIH)/National Centre for Complementary and Alternative Medicine (NCCAM). It was believed that the healers/practitioners channel the energy from the environment and direct it towards certain target [16-18]. Thus, the human has the ability to harness the energy from the environment and can transmit it to any living or non-living object(s) around the Globe. By absorbing this energy, the object will respond in a useful way. This process is known as biofield energy treatment. Mr. Trivedi is well known to possess a unique biofield energy treatment (The Trivedi Effect ${ }^{\circledR}$ ). The impact of his biofield energy treatment has been reported for causing alterations in various research field viz. agriculture, microbiology, biotechnology [19, 20], and materials science $[12,13]$. Hence, the present study was designed to analyse the impact of the biofield energy treatment on the various physicochemical properties of the 2,4-DCP using different analytical methods viz. X-ray diffraction (XRD), differential scanning calorimetry (DSC), thermogravimetric analysis (TGA), Fourier transform infrared (FT-IR) and UV-visible (UV-Vis) spectroscopy.

\section{Materials and Methods}

2,4-Dichlorophenol (2,4-DCP) was procured from Loba Chemie Pvt. Ltd., India. The procured sample was divided into two parts and named as control and treated. Mr. Trivedi's biofield energy treatment was provided to the treated part while no treatment was given to the control part. For treatment, the treated part was handed over to Mr. Trivedi in sealed pack under standard laboratory conditions. Mr. Trivedi provided the treatment to the treated part through his unique energy transmission process. The control and biofield treated samples were further characterized using various analytical techniques.

\subsection{X-ray Diffraction (XRD) Study}

The Phillips Holland PW 1710 X-ray diffractometer system was used to obtain the X-ray powder diffractogram of control and treated samples. The X-ray generator was equipped with a copper anode with nickel filter operating at $35 \mathrm{kV}$ and $20 \mathrm{~mA}$. The XRD system used $1.54056 \AA$ wavelength of radiation. The data were collected from the $2 \theta$ range of $10^{\circ}-99.99^{\circ}$ and a counting time of 0.5 seconds per step along with a step size of $0.02^{\circ}$.

The crystallite size $(\mathrm{G})$ was calculated from the Scherrer equation:

$$
\mathrm{G}=\mathrm{k} \lambda /(\mathrm{b} \operatorname{Cos} \theta)
$$

Where, $\mathrm{k}$ is the equipment constant $(0.94), \lambda$ is the $\mathrm{X}$-ray wavelength $(0.154 \mathrm{~nm}), \mathrm{b}$ in radians is the full-width at half of the peak and $\theta$ is the corresponding Bragg angle. The PowderX software was used to calculate the other parameters viz. lattice parameter, unit cell volume, molecular weight and density of the control and treated samples.

Moreover, the percent change in crystallite size was calculated using the following equation:

Percent change in crystallite size $=\left[\left(\mathrm{G}_{\mathrm{t}}-\mathrm{G}_{\mathrm{c}}\right) / \mathrm{G}_{\mathrm{c}}\right] \times 100$

Here, $G_{c}$ and $G_{t}$ denotes the crystallite size of control and treated powder samples, respectively. Similarly, the percent change in lattice parameter, unit cell volume, molecular weight, and density was calculated to analyse the impact of biofield treatment on crystal parameters of treated sample as compared to the control.

\subsection{Thermal Analysis}

The effect of temperature on the thermal stability profile of 2,4-DCP was analyzed using DSC and TGA/DTG studies. The impact of biofield treatment was analyzed by comparing the results of treated sample with the control sample.

\subsubsection{Differential Scanning Calorimetry (DSC) Study}

The DSC analysis of control and treated sample was carried out using Perkin Elmer/Pyris-1. The control and treated samples were accurately weighed and hermetically sealed in aluminium pans. Further, the samples were heated at a rate of $10^{\circ} \mathrm{C} / \mathrm{min}$ under air atmosphere $(5 \mathrm{~mL} / \mathrm{min})$. The thermograms were collected over the temperature range of $50^{\circ} \mathrm{C}$ to $250^{\circ} \mathrm{C}$. An empty pan sealed with cover pan was used as a reference sample.

\subsubsection{Thermogravimetric Analysis / Derivative \\ Thermogravimetry (TGA/DTG)}

The effect of temperature on the stability of the control and treated samples of 2,4-DCP was analyzed using Mettler Toledo simultaneous thermogravimetric analyser (TGA/DTG). The samples were heated from room temperature to $350^{\circ} \mathrm{C}$ with a heating rate of $5^{\circ} \mathrm{C} / \mathrm{min}$ under air atmosphere. From TGA/DTG curve, the onset temperature, $\mathrm{T}_{\text {onset }}$ (temperature at which sample start losing weight), the end set temperature (temperature at which thermal 
degradation was completed), $\mathrm{T}_{\max }$ (maximum thermal degradation temperature), and percentage weight loss of samples were recorded.

\subsection{Fourier Transform-Infrared (FT-IR) Spectroscopic Characterization}

For FT-IR characterization, the samples were crushed into fine powder and mixed in spectroscopic grade $\mathrm{KBr}$ in an agate mortar. Then the mixture was pressed into pellets with a hydraulic press. The FT-IR spectra were recorded on Shimadzu's Fourier transform infrared spectrometer (Japan) in the frequency range $4000-350 \mathrm{~cm}^{-1}$. The FT-IR spectral analysis was helpful in determining the effect of biofield energy on the strength of bonds and stability of the samples.

\subsection{UV-Vis Spectroscopic Analysis}

The UV-Vis spectral analysis was measured using Shimadzu UV-2400 PC series spectrophotometer. The spectrum was recorded with $1 \mathrm{~cm}$ quartz cell having a slit width of $2.0 \mathrm{~nm}$ over a wavelength range of $200-400 \mathrm{~nm}$. This study helps to investigate any change in the electron transfers behavior between the orbitals or bands of atoms, ions and molecules from the ground state to the first excited state.

\section{Results and Discussion}

\subsection{X-ray Diffraction (XRD)}

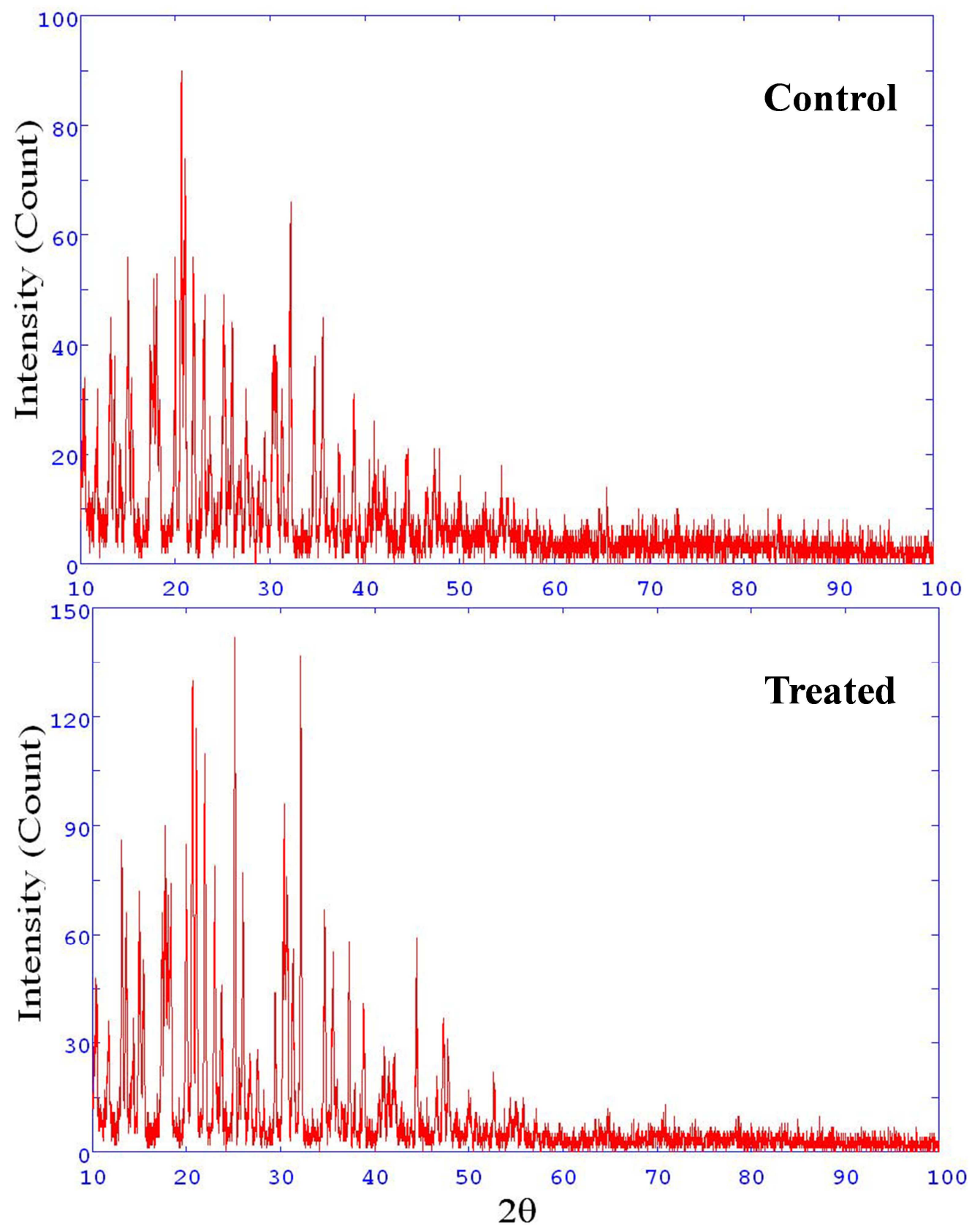

Fig. 1. XRD diffractograms of control and treated samples of 2,4-dichlorophenol. 


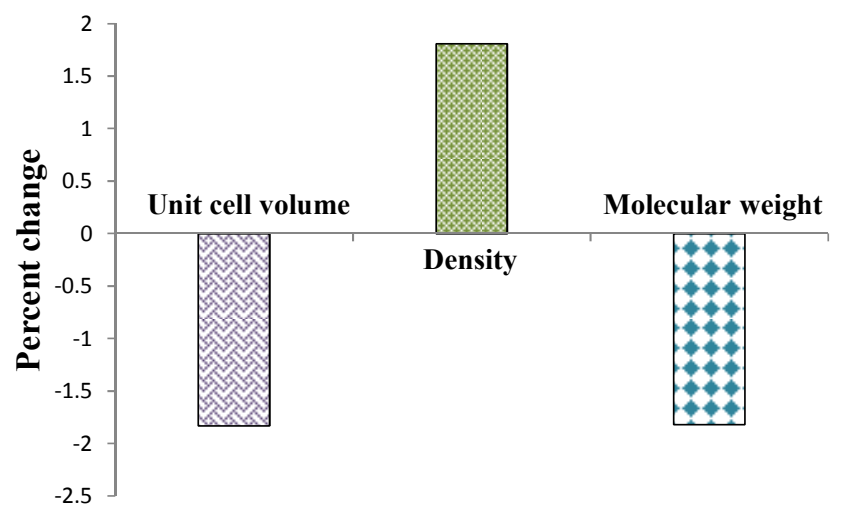

Fig. 2. Percent change in crystal parameters of treated 2,4-dichlorophenol.

The X-ray powder diffractograms of control and treated samples of 2,4-DCP are presented in Fig. 1. The diffractograms showed a series of sharp peaks in the regions of $10^{\circ}<2 \theta>50^{\circ}$. The sharp peaks in the diffractograms showed the crystalline nature of 2,4-DCP [21]. In addition, the most intense peak in control sample was observed at $2 \theta$ equal to $20.62^{\circ}$; however, in treated sample it was observed at $32.11^{\circ}$. It indicated that the relative intensities of XRD peaks were altered in the treated 2,4-DCP as compared to the control sample. Moreover, the crystal structure parameters such as lattice parameter, unit cell volume, density, and molecular weight were computed using PowderX software. The results are presented in Table 1, and the data showed that the lattice parameter 'a' was increased by $19.4 \%$, whereas 'c' was decreased by $2.44 \%$ in the treated sample as compared to the control. Similarly, the unit cell volume, molecular weight, and density were also altered in the treated sample as compared to the control (Fig. 2). It was reported that the temperature has a significant impact on the crystal parameter, and it is directly related to the lattice parameter [22]. Hence, it is assumed that the biofield treatment provided some energy to the treated sample due to which its lattice parameter was increased as compared to the control. Besides, the crystallite size of the control sample was found as 84.08 $\mathrm{nm}$ whereas; in the treated sample it was found as $215.24 \mathrm{~nm}$. It suggested that crystallite size of the treated sample was significantly increased by $155.99 \%$ as compared to the control. Furthermore, it is assumed that biofield treatment might induce some internal strain in the treated sample that resulted in the re-orientation of neighboring planes in the same planes. This may lead to increased crystallite size in the treated sample of 2,4-DCP [12]. The decrease in the crystallite size may results in decreasing the lattice parameter and vice versa [23]. Hence, the alteration in crystallite size was supported by the result of lattice parameter. Besides, the process of degradation through volatilization increases with the decrease in the molecular weight. Also, the less water soluble chemicals tend to be on the water surface and hence increased volatilization [24]. It was observed that the biofield treated 2,4-DCP had decreased molecular weight as compared to the control sample. Moreover, the crystallite size was increased in the treated sample, which can be further correlated with increased particle size, and hence decreased solubility [25]. Both parameters of treated sample suggested the possible increase in decomposition of the biofield treated 2,4-DCP through the process of volatilization in the environment as compared to the control.

Table 1. X-ray diffraction analysis of control and treated 2,4-dichlorophenol.

\begin{tabular}{lll}
\hline Parameter & Control & Treated \\
\hline Lattice parameter & & \\
$\mathrm{a}(\AA)$ & 30.05 & 35.88 \\
$\mathrm{~b}(\AA)$ & 24.23 & 23.64 \\
Unit cell volume $\left(\times 10^{-21} \mathrm{~cm}^{3}\right)$ & 3.175 & 3.117 \\
Density $\left(\mathrm{w} / \mathrm{cm}^{3}\right)$ & 1.709 & 1.740 \\
Crystallite size $(\mathrm{nm})$ & 84.08 & 215.24 \\
\hline
\end{tabular}

\subsection{Thermal Analysis}

The DSC analysis of control and treated samples of 2,4DCP are presented in Table 2. The peak width of samples revealed that both samples exhibited a broad endothermic peak, in which the control sample exhibited it at $137.90^{\circ} \mathrm{C}$, whereas the treated sample exhibited the similar broad peak at $131.94^{\circ} \mathrm{C}$. The peaks are due to the decomposition of the control and treated samples of 2,4-DCP that occurs through the process of vaporization as suggested by the literature [26]. The result suggested about $6^{\circ} \mathrm{C}$ decrease in the decomposition temperature of the treated sample as compared to the control. However, a very slight alteration was observed in the onset and end set temperature of the decomposition as well as the peak width in the control and treated samples. The data also showed that the control sample absorbed $90.83 \mathrm{~J} / \mathrm{g}$ of heat in this process, whereas the treated sample absorbed $174.57 \mathrm{~J} / \mathrm{g}$ of heat. It indicated that amount of heat absorbed was significantly increased by $92.19 \%$ in the treated sample as compared to the control. The heat needed to decompose/vaporize the sample is related to the internal energy of the molecules. It is presumed that biofield energy might alter the internal energy stored in the molecules of the treated sample.

Table 2. Differential scanning calorimetry analysis of 2,4-dichlorophenol.

\begin{tabular}{llll}
\hline Parameter & Control & Treated & Percent change \\
\hline Onset temperature $\left({ }^{\circ} \mathrm{C}\right)$ & 126.40 & 127.65 & 0.99 \\
Peak temperature $\left({ }^{\circ} \mathrm{C}\right)$ & 137.90 & 131.94 & -4.32 \\
Endset temperature $\left({ }^{\circ} \mathrm{C}\right)$ & 143.73 & 145.95 & 1.54 \\
Peak width $\left({ }^{\circ} \mathrm{C}\right)$ & 17.33 & 18.30 & 0.06 \\
$\Delta \mathrm{H}(\mathrm{J} / \mathrm{g})$ & 90.83 & 174.57 & 92.19 \\
\hline
\end{tabular}

Besides, the TGA/DTG studies revealed the change in weight of sample during thermal decomposition. The TGA/DTG thermograms of the control and treated samples of 2,4-DCP are presented in Fig. 3, and data are presented in Table 3. The control sample started to decompose around $101.5^{\circ} \mathrm{C}$ (onset), and the process of decomposition was completed around $135.5^{\circ} \mathrm{C}$ (end set). However, the treated sample started losing weight around $95^{\circ} \mathrm{C}$ (onset) and terminated around $142^{\circ} \mathrm{C}$ (end set). It indicated that onset temperature was decreased while the end set temperature was 
increased in the treated sample as compared to the control. In this process, the control sample lost $59.12 \%$ of its initial weight; however the treated sample lost $71.74 \%$ of its initial weight. The weight loss mainly occurred due to the volatilization/vaporization of the sample after heating. From this data, it was observed that the total weight loss in the treated sample was increased during its decomposition as compared to the control. Besides, DTG thermogram data showed that $\mathrm{T}_{\max }$ was observed at $120.54^{\circ} \mathrm{C}$ in the control sample and $119.31^{\circ} \mathrm{C}$ in the treated $2,4-\mathrm{DCP}$ sample. It indicated that $\mathrm{T}_{\max }$ was slightly decreased in treated sample as compared to the control. Furthermore, the decrease in onset temperature of decomposition, $\mathrm{T}_{\max }$, and increased weight loss in the treated sample of 2,4-DCP with respect to the control sample (Fig. 4) may be correlated with the decreased thermal stability and increase in volatilization of the treated sample after biofield treatment. It was reported that in 2,4-DCP molecules, the phenolic $\mathrm{H}$ atom possess the intermolecular hydrogen bonding [27]. Moreover, the bonding between the neighboring molecules may results in packed molecules resulting in higher thermal stability [28]. It is assumed that biofield energy was absorbed by the treated sample that might break the hydrogen bonding between the molecules. Due to this the thermal stability of the treated sample was reduced as compared to the control sample. The treated sample with increased volatility suggested the increased degradation of the treated 2,4-DCP in the environment through the process of vaporization as compared to the control sample.

Table 3. Thermogravimetric analysis of 2,4-dichlorophenol.

\begin{tabular}{lll}
\hline Parameter & Control & Treated \\
\hline Onset temperature $\left({ }^{\circ} \mathrm{C}\right)$ & 101.50 & 95.00 \\
Peak temperature $\left({ }^{\circ} \mathrm{C}\right)$ & 120.54 & 119.31 \\
Endset temperature $\left({ }^{\circ} \mathrm{C}\right)$ & 135.50 & 142.00 \\
Peak width $\left({ }^{\circ} \mathrm{C}\right)$ & 34.00 & 47.00 \\
Change in weight $(\%)$ & -59.12 & -71.74 \\
\hline
\end{tabular}
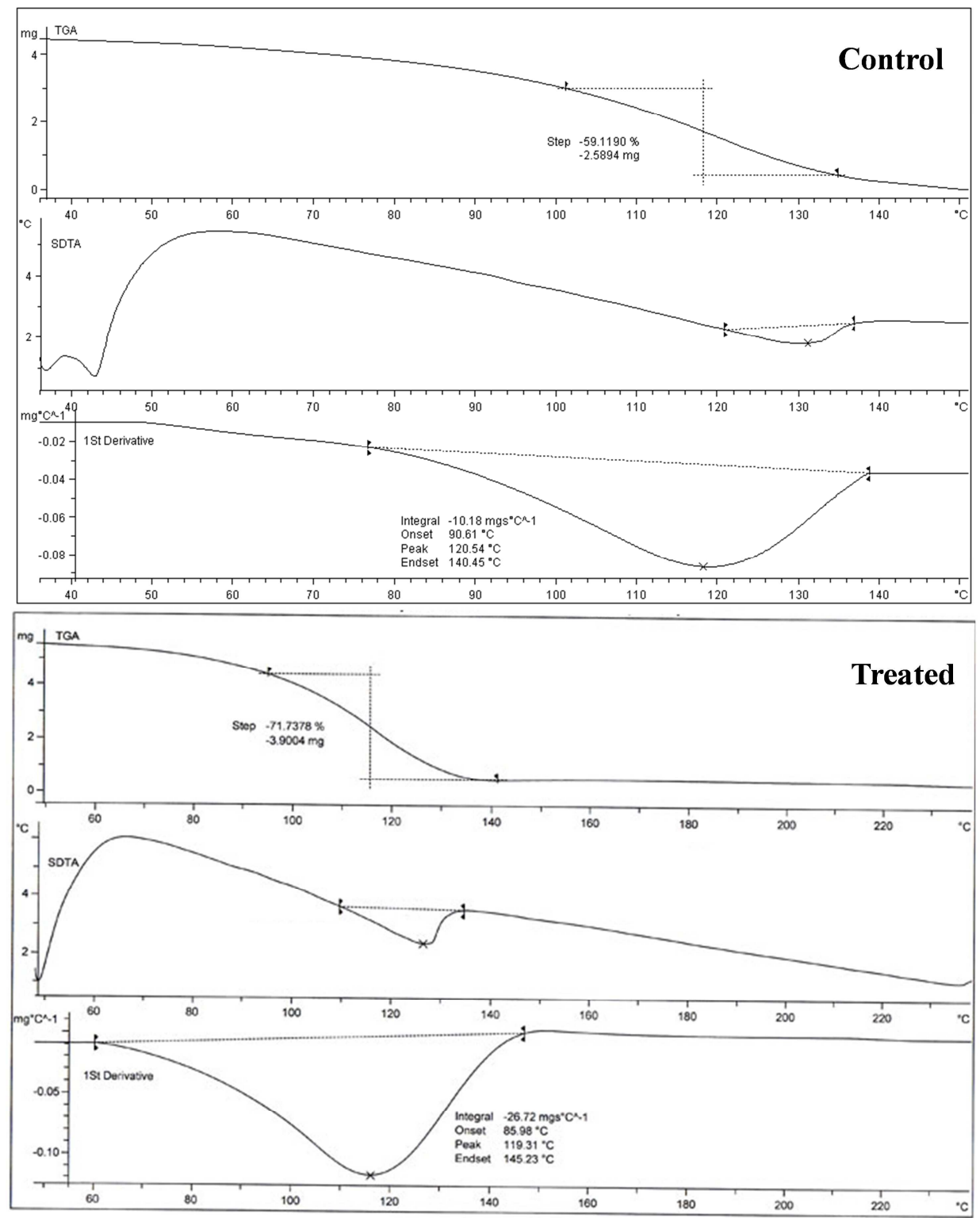

Fig. 3. TGA/DTG thermograms of control and treated samples of 2,4-dichlorophenol. 


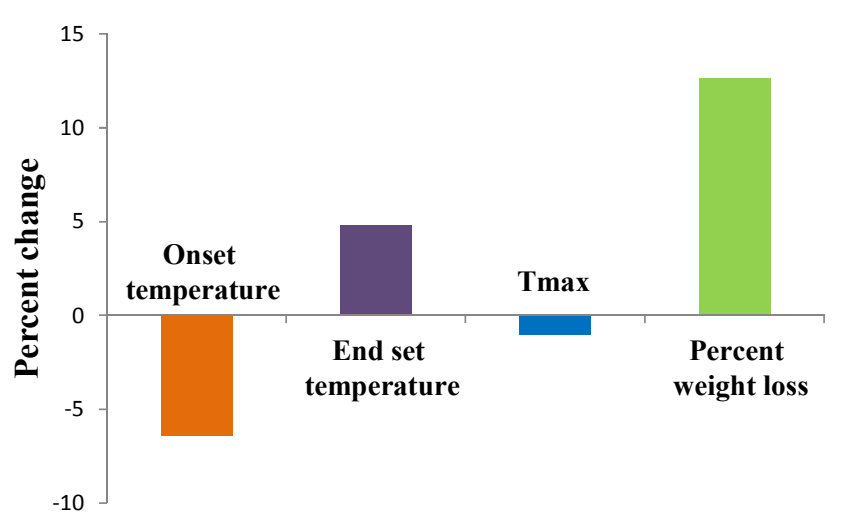

Fig. 4. Percent change in thermal analysis parameters of treated sample.

\subsection{FT-IR Spectroscopic Analysis}

The FT-IR spectra of control and treated samples of 2,4DCP are shown in Fig. 5. The major vibration peaks observed were as follows:

$\mathrm{O}-\mathrm{H}$ vibrations
The $\mathrm{OH}$ group gives rise to three vibrations: stretching, inplane bending and out-of-plane deformations. In the present study, the strong band observed at $3437 \mathrm{~cm}^{-1}$ in control and $3435 \mathrm{~cm}^{-1}$ in the treated sample was assigned to O-H stretching mode of vibration. The peaks observed at 1251 and $653 \mathrm{~cm}^{-1}$ in both, control and treated samples were assigned to $\mathrm{OH}$ in-plane and out-of-plane bending vibration, respectively.

\section{$\mathrm{C}-\mathrm{O}$ vibrations}

The C-O stretching vibration peak was observed at 1184 $\mathrm{cm}^{-1}$ in the control sample and $1186 \mathrm{~cm}^{-1}$ in the treated sample. Moreover, the peak due to $\mathrm{C}-\mathrm{O}$ in-plane bending was appeared as merged with the $\mathrm{O}-\mathrm{H}$ out-of-plane bending at $653 \mathrm{~cm}^{-1}$ in both, control and treated samples.

Aromatic C-H vibrations

The aromatic $\mathrm{C}-\mathrm{H}$ stretching vibration was observed as a weak band at $3091 \mathrm{~cm}^{-1}$ in both, control and treated samples. Similarly, the in-plane $\mathrm{CH}$ bending peaks were observed at 1238 and $1093 \mathrm{~cm}^{-1}$ in both, the control and treated samples.

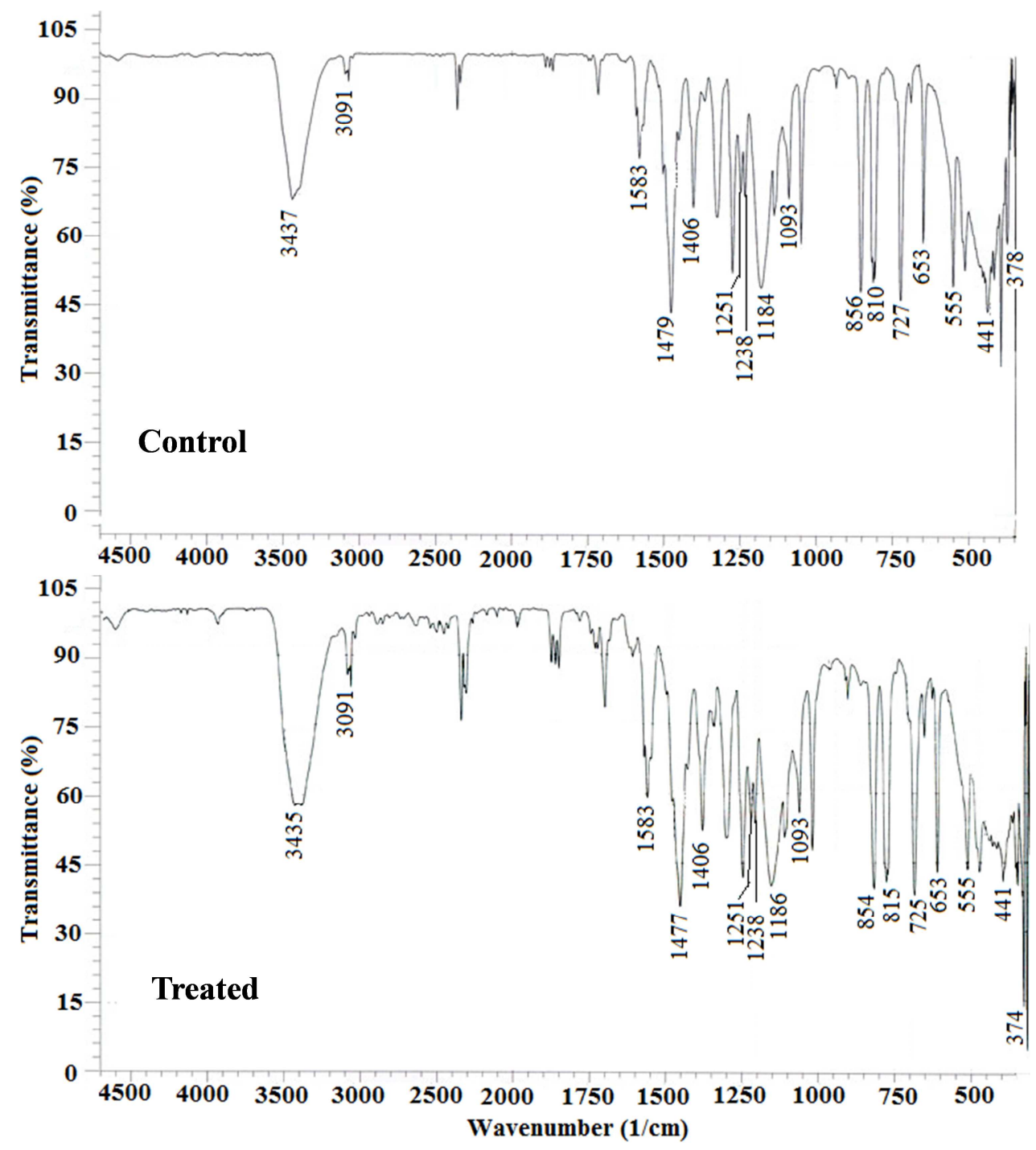

Fig. 5. FT-IR spectra of control and treated samples of 2,4-dichlorophenol. 


\section{C-C vibrations}

The C-C aromatic stretching peaks were observed at 1479 and $1406 \mathrm{~cm}^{-1}$ in the control sample; whereas 1477 and 1406 $\mathrm{cm}^{-1}$ in the treated sample. Moreover, the C-C-C in-plane bending peak $\left(441 \mathrm{~cm}^{-1}\right)$ and out-of-plane bending peak (555 $\mathrm{cm}^{-1}$ ) were observed at the same frequency in both, control and treated samples.

C-Cl vibrations

The control and treated 2,4-DCP showed a very strong band of $\mathrm{C}-\mathrm{Cl}$ stretching due to the presence of two chlorine atoms. In the FT-IR spectra, $\mathrm{C}-\mathrm{Cl}$ stretching was observed at 727 and $725 \mathrm{~cm}^{-1}$ as the strong, sharp bands in control and treated samples, respectively. The $\mathrm{C}-\mathrm{Cl}$ in-plane bending peak has appeared at $378 \mathrm{~cm}^{-1}$ in the control and $374 \mathrm{~cm}^{-1}$ in the treated sample.

Ring vibrations

The ring stretching vibration peak was observed at 1583 $\mathrm{cm}^{-1}$ in both control and treated samples. Moreover, the 1,2,4-trisubstituted benzene ring showed a doublet peak in the region of $750-850 \mathrm{~cm}^{-1}$ [29]. In the present study, the peaks were observed at 810 and $856 \mathrm{~cm}^{-1}$ in the control sample, while 815 and $854 \mathrm{~cm}^{-1}$ in the treated sample.

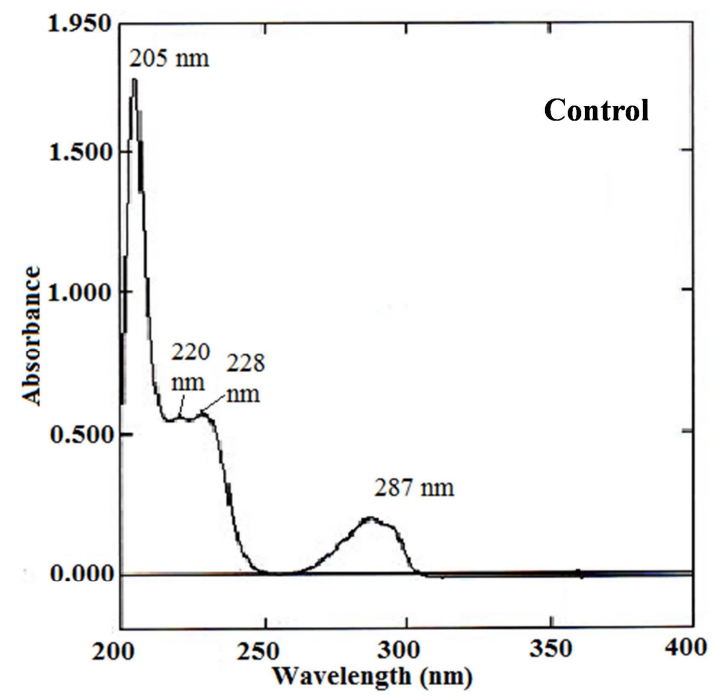

Fig. 6. UV-Vis spectra of control and treated samples of 2,4-dichlorophenol.

\section{Conclusions}

The overall study was accomplished to determine the impact of biofield treatment on various physicochemical properties of the sample of 2,4-DCP. The XRD results showed an alteration in the lattice parameters and molecular weight along with $156 \%$ increase in crystallite size of the treated sample as compared to the control. It suggested the presence of some internal strain due to the biofield energy treatment. Moreover, the increased crystallite size may ensure the less solubility of the treated sample; thereby the sample remained on the water surface and hence might result in more volatilization. Besides, the thermal analysis data revealed the decreased thermal stability and increased vaporization of the treated sample as compared to the control.
The FT-IR spectrum of the control sample of 2,4-DCP was well supported by literature [29,30]. The FT-IR spectra of treated 2,4-DCP sample showed the similar pattern of IR absorption peaks as the control sample. It suggested that biofield energy treatment did not cause any significant alteration in the bond strength, dipole strength, etc. of the treated sample.

\subsection{UV-Vis Spectroscopic Analysis}

The UV spectra of control and treated samples of 2,4-DCP are shown in Fig. 6. The UV spectrum of control sample showed absorption peaks at $\lambda_{\max }$ equal to 205, 220, 228, and $287 \mathrm{~nm}$. The spectrum of control sample was well supported by the literature $[31,32]$.

However, the biofield treated sample showed absorption peaks at 206, 229, and $287 \mathrm{~nm}$. The $\lambda_{\max }$ was found similar in both, the control and treated samples, except the peak at 220 $\mathrm{nm}$ in the control sample that was not observed in the treated sample. The peak at $220 \mathrm{~nm}$ was probably merged in the peak at $229 \mathrm{~nm}$ in the treated sample.

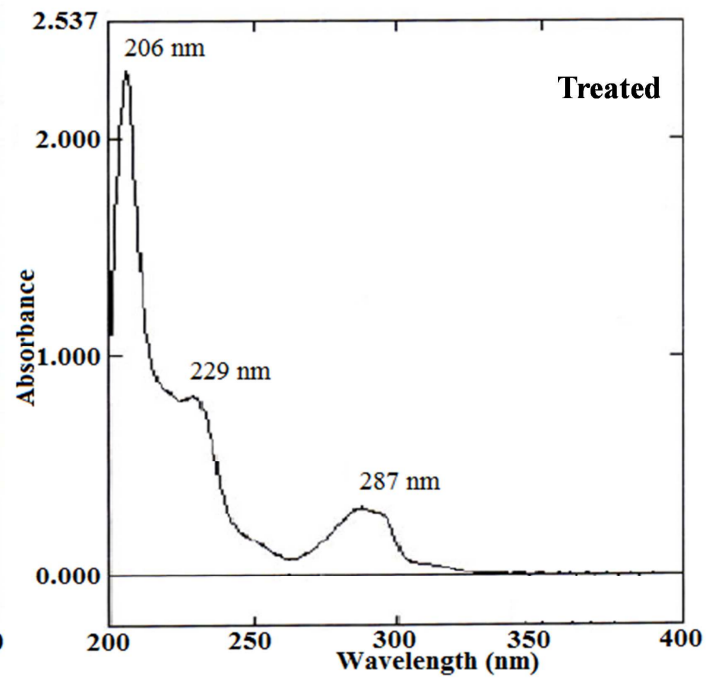

It probably occurred due to the breaking of intermolecular hydrogen bonding after biofield treatment. The decreased thermal stability of the treated sample suggests its fast vaporization from ground and water surface to the atmosphere where it can further degrade by reacting with photo-chemically produced free radicals. Hence, it was concluded that the biofield treated 2,4-DCP could be less harmful to the environment due to their fast degradation process.

\section{Acknowledgements}

Authors are very grateful for the support of Trivedi Science, Trivedi Master Wellness and Trivedi Testimonials in this research work. The authors would also like to acknowledge the 
whole team from the Sophisticated Analytical Instrument Facility (SAIF), Nagpur and MGV Pharmacy College, Nashik for providing the instrumental facility.

\section{References}

[1] Pera-Titus M, Garcia-Molina V, Banos MA, Gimenez J, Esplugas S (2004) Degradation of chlorophenols by means of advanced oxidation processes: A general review. Appl Catal B Environ 47: 219-256.

[2] Sabhi S, Kiwi J (2001) Degradation of 2,4-dichlorophenol by immobilized iron catalysts. Water Res 35: 1994-2002.

[3] Sponza DT, Ulukoy A (2008) Kinetic of carbonaceous substrate in an upflow anaerobic sludge blanket (UASB) reactor treating 2,4-dichlorophenol (2,4 DCP). J Environ Manage 86: 121-131.

[4] Temel NK, Sokmen M (2011) New catalyst systems for the degradation of chlorophenols. Desalination 281: 209-214.

[5] Hendricks NR, Waryo TT, Arotiba O, Jahed N, Baker PGL, et al. (2009) Microsomal cytochrome P450-3A4 (CYP3A4) nanobiosensor for the determination of 2,4-dichlorophenol-an endocrine disruptor compound. Electrochim Acta 54: 19251931.

[6] Rathore HS, Nollet LML (2012) Pesticides: Evaluation of environmental pollution. CRC press, Florida.

[7] Domb AJ, Kost J, Wiseman D (1998) Handbook of biodegradable polymers. CRC Press, Florida.

[8] Shiu WY, Ma KC, Varhanickova D, Mackay D (1994) Chlorophenols and alkylphenols: A review and correlation of environmentally relevant properties and fate in an evaluative environment. Chemosphere 29: 1155-1224.

[9] Lyman WJ, Reehl WF, Rosenblatt DH (1982) Handbook of chemical property estimation methods: Environmental behaviour of organic compounds. McGraw-Hill, Washington, DC.

[10] Altschuh J, Bruggemann R, Santl H, Eichinger G, Piringer OG (1999) Henry's law constant for a diverse set of organic chemicals: Experimental determination and comparison of estimation methods. Chemosphere 39: 1871-1887.

[11] Gupta SS, Stadler M, Noser CA, Ghosh A, Steinhoff B, et al. (2002) Rapid total destruction of chlorophenols by activated hydrogen peroxide. Science 296: 326-328.

[12] Trivedi MK, Nayak G, Patil S, Tallapragada RM, Latiyal O, et al. (2015) Characterization of physical and structural properties of brass powder after biofield treatment. J Powder Metall Min 4: 134.

[13] Trivedi MK, Patil S, Mishra RK, Jana S (2015) Structural and physical properties of biofield treated thymol and menthol. J Mol Pharm Org Process Res 3: 127.

[14] Prakash S, Chowdhury AR, Gupta A (2015) Monitoring the human health by measuring the biofield "aura": An overview. Int J Appl Eng Res 10: 27654-27658.

[15] Rubik B (2002) The biofield hypothesis: Its biophysical basis and role in medicine. J Altern Complement Med 8: 703-717.
[16] Mager J, Moore D, Bendl D, Wong B, Rachlin K, et al. (2007) Evaluating biofield treatments in a cell culture model of oxidative stress. Explore 3: 386-390.

[17] Uchida S, Iha T, Yamaoka K, Nitta K, Sugano H (2012) Effect of biofield therapy in the human brain. J Altern Complement Med 18: 875-879.

[18] NIH, National Center for Complementary and Alternative Medicine. CAM Basics. Publication 347. [October2008]. Available at: http://nccam.nih.gov/health/whatiscam/.

[19] Trivedi MK, Patil S, Shettigar H, Gangwar M, Jana S (2015) An effect of biofield treatment on multidrug-resistant Burkholderia cepacia: A multihost pathogen. J Trop Dis 3: 167.

[20] Nayak G, Altekar N (2015) Effect of biofield treatment on plant growth and adaptation. J Environ Health Sci 1: 1-9.

[21] Rudrangi SR, Bhomia R, Trivedi V, Vine GJ, Mitchell JC, et al. (2015) Influence of the preparation method on the physicochemical properties of indomethacin and methyl- $\beta$ cyclodextrin complexes. Int J Pharm 479: 381-390.

[22] Muniraju NKC (2012) Crystal and spin structure and their relation to the physical properties in some geometrical and spin spiral multiferroics. Forschungszentrum Julich, Germany.

[23] Sui ML, Lu K (1994) Variation in lattice parameters with grain size of nanophase $\mathrm{Ni}_{3} \mathrm{P}$ compound. Mater Sci Eng A Struct Mater 179-180: 541-544.

[24] Linde CD (1994) Physico-chemical properties and environmental fate of pesticides. Environmental monitoring and pest management branch, California.

[25] Hefter GT, Tomkins RPT (2003) The experimental determination of solubilities. Wiley series in solution chemistry. John Wiley and Sons.

[26] http://www.ilo.org/dyn/icsc/showcard.display?p_card_id=0438.

[27] Cai XQ, Jin ZM (2014) A hydrogen-bonded three-component complex: bis (dicyclohexylammonium) 2,4-dichlorophenolate 2,4,6-trichlorophenolate 2,4-dichlorophenol. Acta Crystallogr C Struct Chem 70: 207-209.

[28] Poletto M, Zattera AJ, Forte MM, Santana RM (2012) Thermal decomposition of wood: Influence of wood components and cellulose crystallite size. Bioresour Technol 109: 148-153.

[29] Sundaraganesan N, Anand B, Dominic Joshua B (2006) FTIR, FT-raman spectra and $a b$ initio DFT vibrational analysis of 2,4-dichloro-6-nitrophenol. Spectrochim Acta A Mol Biomol Spectrosc 65: 1053-1062.

[30] Lambert JB (1987) Introduction to organic spectroscopy. Macmillan, New York, USA.

[31] Zhang YZ, Zhang NX, Ren AQ, Zhang J, Dai J, et al. (2010) Spectroscopic studies on the interaction of 2,4-dichlorophenol with bovine serum albumin. J Solution Chem 39: 495-510.

[32] Es'haghi Z (2011) Extraction and determination of three chlorophenols by hollow fiber liquid phase microextractionSpectrophotometric analysis, and evaluation procedures using mean centering of ratio spectra method. Am J Analyt Chem 2: $1-8$. 